\title{
THE PENITENTIARY AND PERFECTIBILITY IN TOCQUEVILLE
}

\author{
JOEL SCHWARTZ \\ University of Michigan
}

LEXIS DE TOCQUEVILLE'S first book, a co-authored study of
the American penitentiary system, is a little-known work which is
nevertheless of considerable theoretical interest. It represents Tocqueville's initial statement of his views concerning issues with which he was to deal throughout his career, such as the political roles of religion and of intellectuals, and the relation of theory to practice. Not only does the book serve as a useful introduction to Tocqueville's views, however; more importantly, it helps to answer various questions to which Tocqueville's later, better-known works do not fully respond. In particular, The Penitentiary System offers us a thoughtful presentation of Tocqueville's analysis of the problems and prospects of democratic reformism - the practical expression of the democratic belief in human perfectibility.

In view of the claims that I make for the work, the relative oblivion into which it has been cast by political theorists, and specifically by Tocqueville scholars, ${ }^{1}$ may be a matter of some surprise. Two reasons account for the lack of attention paid the work. First, the main text of the book was written not by Tocqueville himself, but instead by Gustave de Beaumont, Tocqueville's close friend and companion on his voyage to America; Tocqueville's own contribution was limited to the notes and appendices (Drescher 1968: 130-31). Secondly, I believe that scholars have assumed that a book about penitentiaries must be narrowly technical, perhaps of interest to penologists, but at any rate devoid of material relevant to Tocqueville's serious concern, the study of democracy.

With regard to the first reason, one can observe that Tocqueville's notes and appendices consisted of more than two hundred pages, and have with reason been described as "a small encyclopedia of information and surprises" (Pierson 1938: 705). In addition, even if the main text is Beaumont's, Beaumont was Tocqueville's closest friend and intellectual collaborator throughout his life. The most fundamental considerations, however, are the following: in the course of presenting "A Rationale for [the] Collective Study [of] Tocqueville and Beaumont," Drescher notes that "the identity of [Beaumont and Tocqueville's] views [on penitentiary reform] was never broken" (Social Reform 210). To this Boesche (1980: 550 ) adds that "Beaumont and Tocqueville had a unique relationship in

\footnotetext{
${ }^{1}$ See Boesche, 1980 (the only article on Tocqueville's study of the penitentiary of which I am aware), p. 550: "Only two of his commentators [namely Pierson 1938, and Drescher 1968] cast more than an obligatory glance toward Tocqueville's concern with prisons, and even these two merely report Tocqueville's thought, displaying no inclination to analyze its significance." Boesche's article itself is complementary to but quite different from mine: it focuses on democratic despotism, whereas my concern here is with the democratic belief in perfectibility.
} 
that neither would publish anything - at least when they were young until they had thoroughly discussed the ideas involved and reached a common position; thus they almost never disagreed. ... Certainly Tocqueville read and approved of every word in the book [on penitentiaries]." For these reasons, he concludes, "with J. P. Mayer, we may feel safe in calling this work on American prisons 'Tocqueville's first book'."

My chief concern, however, is to rebut the second presupposition against the significance of Beaumont and Tocqueville's study of the penitentiary. I have already asserted that the book's importance lies in its analysis of the democratic view of perfectibility, which is the theoretical basis of democratic reformism; so as to substantiate the assertion, I now turn to a consideration of Tocqueville's discussions of perfectibility in his other works.

\section{Democracy ANd Perfectibility}

To what extent is social reform possible in democracies? To what extent do democratic peoples believe that they can reform and perfect their societies? The answers given by Tocqueville to these questions in Democracy in America are ambiguous if not contradictory. On the one hand, he suggests that democratic peoples constantly see changes taking place, and come to believe that nothing is immutable, that they can shape the world to suit themselves. Equality suggests to them the "philosophic theory of the indefinite perfectibility of man," which has "a prodigious influence" upon them (Democracy 453). Without giving specific examples, Tocqueville concludes his short discussion of the democratic belief in perfectibility by warning that "democratic nations sometimes stretch [the scope of human perfectibility] beyond reason" (Democracy 454).

On the other hand, soon afterwards, in discussing democratic historians, Tocqueville seems radically to reverse this judgement: democratic man no longer appears as Prometheus, confident of his ability to transform the world, but instead as Oedipus, despairing at his inability to escape his fate. Equality lessens the impact that particular individuals can make upon the world; accordingly, democratic historians explain change in terms of general laws (whether economic, geographical, or racial) that control the actions of human beings, but are beyond the control of human beings. Such philosophies of history are pernicious in practice, whatever their theoretical merits, because they call human freedom into question. Democratic historians "take away from the peoples themselves the faculty of modifying their own lot and make them depend either on an inflexible providence or on a kind of blind fatality" (Democracy 496). Tocqueville fears that their influence "will soon paralyze the activities of modern society and bring Christians down to the level of Turks" (Democracy 496).

Thus Tocqueville points to two seemingly contradictory democratic views: democrats are prone to exaggerate either their ability consciously to perfect the world or their total inability consciously to affect its trans- 
formation. Tocqueville was later to chart these same two unsatisfactory extremes in a highly illuminating letter to Gobineau: ${ }^{2}$

The last century had an exaggerated and somewhat childish trust in the control which men and peoples were supposed to have of their own destinies. It was the error of those times. . . The weary aftermath of revolutions, the weakening of passions, the miscarriage of so many generous ideas and of so many great hopes have now led us to the opposite extreme. After having felt ourselves capable of transforming ourselves, we now feel incapable of reforming ourselves; after having had excessive pride, we have now fallen into excessive self-pity; we thought we could do everything, and now we think we can do nothing. . . This is really the great sickness of our age; it is very different from that of our parents. (Gobineau 231-32.)

At the highest level, Tocqueville's attempt to chart a mean between the extremes of absolute freedom and absolute determinism underlies his whole philosophy of history. This is the import of the celebrated conclusion to Democracy in America: "Providence did not make mankind entirely free or completely enslaved. Providence has, in truth, drawn a predestined circle around each man beyond which he cannot pass; but within those vast limits man is strong and free, and so are peoples" (Democracy 705).

Unfortunately, as has been widely recognized, Tocqueville's attempted resolution of the problem of freedom and determinism leaves as many questions asked as it answers (see Lively 1962: 39, Zetterbaum 1967: 12). We are not told within what limits human beings are free, why they are free thus far but no further. The other Tocquevillian passages that $I$ have cited are equally ambiguous, because equally unspecific. The chapter on perfectibility in Democracy in America gives us no concrete illustrations of the democratic extension of the scope of human perfectibility "beyond reason"; nor does the letter to Gobineau explain the distinction between the utopian hope of "transforming ourselves" and the realistic expectation of "reforming ourselves."

Beaumont and Tocqueville's study of the American penitentiary system is of interest and importance in that it can help to resolve the problem sketched above. To be sure, it presents no solution to the problem of freedom and determinism in a metahistorical context. But more than any of the works written by Tocqueville alone, it does concretely examine one particular attempt by a democratic society to achieve reform, to perfect itself, specifically by means of the moral rehabilitation of criminals.

${ }^{2}$ It is noteworthy that Tocqueville accuses Gobineau himself of each of these vices at different stages of the latter's intellectual evolution. In 1843, Tocqueville thinks that Gobineau, at age twenty-seven, is too confident of his ability to effect wholesale changes: "The only difference between you and me is that you have more ambition than $I$ have. ... You want to change the face of the world, nothing less. I am more modest" (Gobineau 211). Conversely, Tocqueville rejects the racist theories propounded by Gobineau as of 1853 , because of their materialistic and predestinarian implications: "The consequence ... is . . . a vast limitation, if not a complete abolition of human liberty. Thus I confess that after having read your book I remain, as before, opposed in the extreme to your doctrine" (Gobineau 227). 
Precisely this emphasis, to be sure, might be thought to indicate the irrelevance of Beaumont and Tocqueville's study to present-day political concerns; for virtually no one today is so optimistic as to believe that incarceration in penitentiaries can facilitate the rehabilitation of a significant percentage of convicted criminals. ${ }^{3}$ Thus a highly respected social scientist, who specializes in the study of crime, rightly claims that "today we smile in amusement at the naiveté of those early prison reformers [e.g., those whose work Beaumont and Tocqueville analyzed and to a large extent admired] who imagined that religious instruction while in solitary confinement would lead to moral regeneration" (Wilson 1983: 163); thus a Tocqueville scholar, even while defending the importance of Tocqueville's interest in the penitentiary, acknowledges that it seems to be a "modest and anachronistic" "corner of Tocqueville's thought" (Boesche 1980: 550).

Yet in spite of its focus upon a public policy measure whose inefficacy is now by and large universally accepted, The Penitentiary System speaks to political issues that are still of genuine interest today. This is true both narrowly and broadly. Narrowly, Beaumont and Tocqueville's discussion of criminal rehabilitation is somewhat less "näve" than one might at first suppose; I will in fact suggest that various approaches whose adoption has been recommended to contemporary criminologists can in some respects be understood as a return to the perspective of Beaumont and Tocqueville. Broadly (and much more significantly), Beaumont and Tocqueville's analysis of the penitentiary reformers is applicable to a much wider array of social reformers, many of whom continue both to exist in and to make an increasingly prominent impact upon democratic societies today. Thus The Penitentiary System is important because it points to both the strengths and the weaknesses of social reform movements; it does so by analyzing the politics and the psychology of reformist attempts to perfect democratic societies generally, by means of its focus upon penitentiary reformers specifically.

The broad applicability of The Penitentiary System's analysis is suggested by the range of the book's subject matter, which deals with far more than penitentiary reform alone. Although the study focuses upon the movement for penitentiary reform, it also pays tangential attention to poor relief, public education, abolitionism, and the temperance movement. ${ }^{4}$

\footnotetext{
${ }^{3}$ See Martinson 1974: 49: "These data, involving over two hundred studies and hundreds of thousands of individuals. ..., are the best available $[; \ldots$ they] give us very little reason to hope that we have in fact found a sure way of reducing recidivism through rehabilitation."

${ }^{4}$ Pierson (1938: 61) notes that "Tocqueville and Beaumont had unwittingly come to the United States at the very moment when a great humanitarian movement was just gathering way"; he alludes to abolitionism, the temperance movement, the promotion of free public education, and the abolition of imprisonment for debt. The first of these movements is discussed in Penitentiary 52; the rest are discussed in three of Tocqueville's appendices to the French text that are omitted from the translation (see Du Systeme Pénitentiare 300-307, 313-15, 316-18). The discussion of poor relief, which also constitutes one of Tocqueville's untranslated appendices, is found on pp. 308-13.
} 
Furthermore, while it is true that penitentiary reform is no longer an issue for democratic reformers today, on Tocquevillian grounds one can nevertheless suggest that there is a kinship between the penitentiary reformers of the past and various social reformers of today (e.g., those whose concern is to eliminate hunger, to achieve excellence in public education, or to protect the environment). For Tocqueville would suggest that all of these sorts of reformers, past and present, share an unmistakably democratic ethos; for in his view, only democrats and not aristocrats accept the assumption upon which their reforms are based - "that man in general is endowed with an indefinite capacity for improvement" (Democracy 453).

For these reasons, The Penitentiary System can be understood as a general study of democratic reformism in America. And in their most sweeping overall assessment of reformism, which explicitly transcends the specific issue of penitentiary reform, Beaumont and Tocqueville "declare that the cause of reform and of progress in the United States seem ... certain and safe" (Penitentiary 52); we will see that it is safe both from those who would deny the possibility of reform and from those who would exaggerate its extent.

Democratic social reform is possible, but it is necessary not to overstate the benefits that it can produce. This is the most important conclusion of The Penitentiary System. On its very first page, Beaumont and Tocqueville observe that "there is not one philanthropic institution, the abuse of which does not border closely on its usefulness" (Penitentiary 34); the main text concludes with their proclamation "of a truth which cannot be neglected without danger, viz., that the abuse of philanthropic institutions is as fatal to society as the evil itself which they are intended to cure" (Penitentiary 158). Nevertheless, if the work rejects utopianism, it is equally critical of fatalism as well: although "it may be true that [the] vicious state of society [caused by the existence of poverty and crime] cannot be cured altogether, it seems equally certain that there are circumstances which tend to aggravate it, and institutions whose influence renders it less fatal" (Penitentiary 35).

Thus do Beaumont and Tocqueville stake out a middle position with respect to democratic reformism. Although reformers cannot achieve as much as the reformers themselves hope to accomplish, neither are they condemned to accomplish as little as the detractors of reform predict. ${ }^{5}$ Radical reformation is impossible because utopian; nevertheless, a more modest and limited reformation, reflecting some of the presuppositions

\footnotetext{
${ }^{5}$ It is interesting to note the affinity between Beaumont and Tocqueville's position and that advocated by James $Q$. Wilson (1983: 56-57), in opposition to sociologists of the left and of the right, who both, he claims, tend to "speak out of ideology, not scholarship.... When [sociologists interested in crime] are brought forward and asked for advice, they will say either (if conservative) that nothing is possible, or (if liberal) that everything is possible." As against both attitudes, Wilson advocates "an experimental attitude toward crime control [adopted by social scientists who] have become, in effect, policy analysts trying to find out what works in the real world." For an indication that Beaumont and Tocqueville's "attitude toward crime control" is "experimental," see note 9 below.
} 
of classical liberalism, is feasible because realistic. In their study, Beaumont and Tocqueville emerge as advocates of this limited, classically liberal reformation, in opposition to both utopians and fatalists. Their middle position prefigures the middle ground later adopted by Tocqueville with respect to the question of freedom and determinism, to which I alluded above: in opposing the utopians, Beaumont and Tocqueville in effect acknowledge that "mankind" is "not . . entirely free"; but in opposing the fatalists, in effect they also assert that "within ... vast limits ... man is ... free" (Democracy 705).

\section{The Critique of Utopian Reformism}

In their report, Beaumont and Tocqueville describe the two rival penitentiary systems brought into being by the American prison reform movement: the Auburn or congregate system (instituted in Auburn, New York between 1819 and 1823, and then in Ossining, better known as Sing Sing, in 1825) and the Philadelphia or separate system (applied in Philadelphia in 1829). In the Auburn plan, prisoners slept alone in their cells at night, and labored together in workshops during the day. They were forbidden in any way to communicate with one another; this prohibition was enforced through the application of corporal punishment. The Philadelphia system, by contrast, isolated each prisoner throughout the period of his confinement; convicts ate, worked, and slept in individual cells. In both systems, prisoners were given the Bible to read, so as to encourage their moral reformation. Only the prison guards and selected visitors (usually clergymen) were permitted to speak with the convicts.

There are obvious similarities between the Auburn and Philadelphia systems, which were based on common principles - convict labor and the isolation of the convicts from one another - that were differently implemented (Penitentiary 56). The chief difference between the two systems followed from the fact that isolation in the Philadelphia penitentiary was continuous, in that prisoners were incarcerated in individual cells day and night; hence the prisoners were restricted to occupations that isolated individuals could pursue, i.e., those for which cooperative labor was unnecessary (Penitentiary 67-68).

Beaumont and Tocqueville point to one vitally important respect in which the two systems resembled one another: "Moral and religious instruction form[ed] . . . the whole basis" of the attempted reformation of convicts in both (Penitentiary 82 ). Throughout their report, Beaumont and Tocqueville emphasize the contribution made by religious figures to the entire American penal reform movement; the role played by religion is central to both the great praise and the small amount of blame that they bestow upon it. "The first idea of a reform in the American prisons, belongs to a religious sect in Pennsylvania": the Quakers' opposition to capital and corporal punishment led to the establishment of the Walnut Street prison (an unsuccessful forerunner of the Philadelphia system) in 1786 (Penitentiary 37-38). Beaumont and Tocqueville contend that "in 
America, the progress of the reform of prisons has been of a character essentially religious. Men, prompted by religious feelings, have conceived and accomplished everything which has been undertaken" (Penitentiary 121; cf. the discussion of "some pious people" in Democracy 249-50).

Beaumont and Tocqueville assert that the principle of solitary confinement for convicts, introduced by the Quakers, "rests upon a philosophical and true conception." But they immediately go on to add that the first experiment with solitary confinement failed, because "the authors of this theory had not yet founded its application upon those means which alone could render it practical" (Penitentiary 39). This statement points to an important theme in Beaumont and Tocqueville's analysis: the contrast with respect to the reformation of prisoners, and ultimately the perfectibility of human nature, between theoretical views (generally with a basis in religion) on the one hand, and practical views on the other. Tocqueville explains that the prison reform movement consisted of a coalition between theoretical and practical reformers: "There are here [in Philadelphia] above all two kinds of men who take a prodigious interest in prisons, although they envisage the subject differently. ... These are the theorists and the practical men: those who write and those who act" (letter to Mme. Édouard of 18 October 1831; quoted in Pierson 1938: 458). We will see that Beaumont and Tocqueville's major reservation about the American penitentiary reform movement specifically, and about democratic reform movements generally, concerns the prevalence of idealistic but sometimes impractical theorists therein. Theoretical reformers like the Quakers undoubtedly benefit society, but the good that they do is to some extent vitiated by their ignorance of practical realities, by their excessive optimism about human nature. The American penal reform movement testifies to the advantages of the humanitarian idealism of the theorists, but Beaumont and Tocqueville are quite aware of its possible dangers as well. Where disagreements exist between "theorists" and "practical men," Beaumont and Tocqueville tend to admire the convictions of the former, but to trust the experiences of the latter.

Beaumont and Tocqueville's ambivalence toward theoretical reformers is reflected in their attitude toward the American tradition of widespread popular participation in politics: they praise it in part because the common people act as a conservative check upon the more theoretical, idealistic, innovative elites.

There are in the United States a certain number of philosophical minds, who, full of theories and systems, are impatient to put them into practice; and if they had the power themselves to make the law of the land, they would efface with one dash, all the old customs, and supplant them by the creations of their own genius, and the decrees of their wisdom. Whether right or wrong, the people do not move so quickly. They consent to changes, but they wish to see them progressive and partial. (Penitentiary 51-52; cf. the contrast between the "conservative interests" of the people 


\section{Western Political Quarterly}

and the "revolutionary instincts" of the "bold innovator," in Democracy 638. $)^{6}$

When reform is "effected by a whole nation," it is "prudent and reserved," insofar as "all of [the nation's] customs are practical"; by contrast, "the enthusiasm of ardent minds and enticing theories" runs the risk of resulting in "precipitated trials" (Penitentiary 52; cf. the contrast between "the heads of society" and "the mass of the population" on p. 197).

Idealistic reformers are too theoretical; they are "estimable men whose minds feed upon philosophical reveries, and whose extreme sensibility feels the want of some illusion" (Penitentiary 80). Because they "start from abstractions which deviate more or less from reality," the theoretical penitentiary reformers exaggerate the good that penal reform can accomplish. Their exaggerated belief in human perfectibility leads them to "hope for an epoch when all criminals may be radically reformed," or to find in "the penitentiary system ... the remedy for all the evils of society" (Penitentiary 80).

Beaumont and Tocqueville believe that the absolute isolation imposed upon prisoners in Philadelphia is more likely to effect their moral reformation than any other conceivable system. Nevertheless, they are profoundly skeptical as to whether radical moral reformation is achievable. "The theories on the reform of the prisoners are vague and uncertain. It is not yet known to what degree the wicked may be regenerated, and by what means this regeneration may be obtained" (Penitentiary 81). They seriously doubt that the prisoners' readings of the Bible and encounters with prison chaplains could lead to complete moral regeneration, to "the radical change of a wicked person into an honest man" (Penitentiary 87). Two prison chaplains estimated that perhaps 7 percent of the inmates of their respective prisons became good Christians; even this modest figure seems too high to Beaumont and Tocqueville (Penitentiary 88). One cannot be certain that radical moral reformation is real, involving as it does the conversion of "the soul," "of the interior forum [that] God alone can judge." "Society" can neither "effect this radical regeneration" nor "prov[e] if it exist" (Penitentiary 88; the emphasis appears in the translation). ${ }^{7}$

${ }^{6}$ Both here and elsewhere, one senses that Beaumont and Tocqueville's reaction against theoretical reformers is influenced by their distaste for the legacy left by theoretical social reformers who attained prominence before and during the French Revolution. The similarity between French and American reformers is nicely conveyed by means of an allusion to the work of Carl Becker in the title of Chapter XXXV of Pierson 1938: "The Heavenly Prison of the Philanthropists." This similarity points to one of the most interesting and important aspects of The Penitentiary System: nowhere in Democracy does America seem as "French" (i.e., theoretical, impractical) as it does on occasion in the earlier work. In other words, Penitentiary usefully supplements Democracy: it makes the analysis of intellectuals in The Old Regime seem more relevant to American democracy than one would expect it to be from a reading of Democracy alone. See pp. 15-17 below, and especially note 10 .

${ }^{7}$ Beaumont and Tocqueville's agnosticism with respect to the moral conversion of prisoners is of theoretical interest, in that it reflects the classical liberal contention that religious belief is an internal matter, beyond the detection and control of political authorities. Cf. Democracy 293: "I do not know if all Americans have faith in their religion - for who can 
In addition, a more practical objection suggests itself: cynical prisoners have a material interest in deluding chaplains into believing in their reformation, which they can hope will lead them to be speedily paroled. Conversely, pious clergymen have an ideal interest in deluding themselves that prisoners have been reformed, since this would testify to the efficacy of their spiritual ministrations (Penitentiary 87-88). Genuine religious reformation either cannot be detected, or else is easily confused with its counterfeit produced by the hypocrisy of one party and the credulity of the other. For this reason,

if the penitentiary system cannot propose to itself an end other than the radical reformation of which we have just spoken, the legislature perhaps should abandon this system; not because the aim is not an admirable one, but because it is too rarely obtained. The moral reformation of an individual, which is an important affair for a religious man, is little for a politician. Or to express it better, an institution is only political if it be founded on the interest of the mass; it loses its character if it only profit a small number. (Penitentiary 89.)

Beaumont and Tocqueville's skepticism regarding the radical reformation of prisoners points to their ultimate preference for the practical prison reformers over the theorists. They base their rejection of radical reformation upon the testimony of practical reformers such as Elam Lynds, the warden of Auburn penitentiary and the founder of Sing Sing; they describe Lynds as a man "who has great experience in prison matters" (Penitentiary 88). ${ }^{8}$ In a conversation with Lynds (printed as an appendix to The Penitentiary System), Lynds tells them to distrust "all [penitentiary] theorists," who "deceive themselves" concerning both the reformation of convicts and "in many other points, ... because they have little knowledge of those of whom they speak" (Penitentiary 164). "Those with practical experience," Tocqueville writes, believe "in the uselessness of the penitentiary system as far as moral reform is concerned" (Journey 23; for further evidence that this is Beaumont and Tocqueville's view as well, see Journey 205 and 208).

Thus Beaumont and Tocqueville's analysis of democratic reformism, as exemplified in the penitentiary reform movement, manifests a certain skepticism about theory, a demand that theory be checked and confirmed or refuted by practice." This was later to become one of Tocqueville's

read the secrets of the heart?" Compare Beaumont and Tocqueville's position with Hobbes 1962: Ch. 40, p. 343: "As for the inward thought, and belief of men, which human governors can take no notice of (for God only knoweth the heart). ..." (The emphases are Hobbes's.) Cf. also Locke 1950: 18. I again allude to the impact of Beaumont and Tocqueville's liberalism upon their view of penitentiary reform on p. 22, below.

${ }^{8}$ Beaumont and Tocqueville's views are not, however, simply identical to those of Lynds. See Penitentiary 88, where they suggest that "perhaps [Lynds] runs into the other extreme," in that he "considers the thorough reformation of a criminal a chimera." See alsoJourney 129, where Tocqueville refers to Lynds's "despotic tendencies."

"Their belief in the need to base theory upon empirical evidence can also be seen in Tocqueville's request to interview prisoners at Eastern State Penitentiary (in Philadelphia), which set a new empirical standard for penology. See Pierson 1938: 464: "Neither 
central themes, both in Democracy in America (Vol. Two, Part I, Ch. 4) and still more prominently in The Old Regime (Part Three, Ch. 1). Mutatis mutandis, one can even detect an affinity between the utopian theorists described in The Penitentiary System and the radical intellectuals denounced in The Old Regime. The former, like the latter, can be said to have "lacked the experience which might have tempered their enthusiasms," thus to have "failed to perceive the very real obstacles in the way of even the most praiseworthy reforms" (The Old Regime 140). ${ }^{10}$

If an affinity between the two types of theorists is evident, great and obvious differences are admittedly evident as well. The penitentiary theorists were devoutly religious, whereas the radical intellectuals were atheists; the penitentiary theorists, such as Roberts Vaux and Edward Livingston, were by and large wealthy philanthropists, men of substance within their communities, ${ }^{11}$ whereas the radical intellectuals were "men of

then nor earlier had it been the practice of even the most conscientious penologists to consult the prisoners for information." (For a transcript of Tocqueville's interviews, see Du Système Pénitentiare 318-36.)

${ }^{10}$ It is puzzling that the influential theoretical reformers, whom Beaumont and Tocqueville repeatedly designate as philosophers (Penitentiary, pp. 39, 45, 52, 80, 85, 116, 197), and who figure so prominently in The Penitentiary System, are barely to be seen in Democracy in America (at least in its more empirical first volume). Tocqueville in fact asserts that "the spirit of the Americans is averse to general ideas and does not seek theoretical discoveries" (Democracy 301; see also 429, 441-42); although he speaks in Democracy of reformist activity in general (see p. 25, below), he never speaks of theoretical reformism in particular.

I believe that two reasons explain the lack of explicit attention paid by Tocqueville to the theoretical reformers in Democracy in America. To begin with, the intellectual impetus behind the prison reform movement came from the American Northeast from Philadelphia, as we have seen, and in the case of the Auburn system from Boston (Penitentiary 46, 193-94). Tocqueville may well have thought that the future impact of theoretical reformers in America was likely to be rather minimal, insofar as the urbanized, civilized Northeast was rapidly being eclipsed by the development of a ruder, uncouth Jacksonian frontier society (see Democracy 55, 200, 278). In addition, one must recall that Tocqueville's book is not about everything in America; it is about democracy in America. Tocqueville's principle of selection in Democracy in America was therefore the relevance of any given phenomenon to the question of equality, as he himself explicitly states (Democracy 417; see Lively, 1962, p. 27). Just as Tocqueville "dropped ... the poor" from Democracy in America, so too did he drop the theorists, and for the very same reason: theorization, like "institutionalized poverty[,] was Amcrican enough but not quite democratic" (Drescher, 1968, pp. 73-76). That is to say, since the most important characteristic of America was its egalitarianism, Tocqueville did not feel himself compelled to highlight the exceptions (whether economic or intellectual) to the egalitarian rule.

As a result of an historical reversal that Tocqueville evidently did not anticipate, however, American intellectuals, so comparatively unimportant for so long, have come to exert considerable political influence, at least since the time of the New Deal (see Shils 1972: 160-75). Thus The Penitentiary System's emphasis upon the political impact of reformist intellectuals ironically enables The Penitentiary System to come closer than Democracy in America, at least in one significant respect, to giving a faithful and recognizable picture of contemporary American democracy.

${ }^{11}$ Vaux and Livingston are two of the prominent penitentiary theorists discussed by Beaumont and Tocqueville (Penitentiary 45). They are described by Pierson (1938: 459-60, $668 \mathrm{n}$ ) in the following terms: Vaux was a man "of character and standing in the community," "unquestionably one of the leading men of the State," who "had helped 
letters, men without wealth, social eminence, responsibilities, or official status" (Old Regime 139).

Important as these differences are, they do not negate the affinity suggested above. The gulf between religious and atheistic theorists is undoubtedly vast, but in Tocqueville's presentation it is not absolute. For the radical French intellectuals were no less animated by a faith than were the Quakers; and Tocqueville describes the faith of the former as "a species of religion," characterized by "an atmosphere of religious fervor." Like the Quaker penitentiary reformers, the radical French intellectuals professed the democratic religion of the perfectibility of man; they aimed at "nothing short of a regeneration of the whole human race" (Old Regime 13; see also 156). Furthermore, Tocqueville occasionally portrays modern humanitarianism (as opposed to socialism) as a secularized form of Christianity (see Gobineau 193, 208, and Social Reform 192). Conversely, the American penitentiary theorists were men of great practical experience and accomplishments; but it is important to realize that their experiences did not extend to the character and behavior of convicted criminals. We have seen Elam Lynds remark that the penitentiary theorists "have little knowledge of those of whom they speak": Livingston, for instance, "always forgets" that "his theories of penitentiaries" are not meant to apply "to people born like himself," but to "coarse beings, who have had no education, and who perceive with difficulty ideas, and often even sensations" (Penitentiary 164). The theoretical reformers had considerable practical experience in their own world, but not much more than good intentions and unexamined aspirations with respect to the world of the prisons' inmates. ${ }^{12}$

Why, then, do Beaumont and Tocqueville assess the American intellectual reformers so much more favorably than Tocqueville was later to assess the radical French intellectuals? Several reasons could be suggested (notably the far greater impact of the latter group upon the evolution of society as a whole); but surely they do so in part because America's democratic reform movement consisted of a coalition between warmhearted theorists and hard-headed practitioners; the rhapsodic utopianism of a Livingston could always be checked by the prosaic empiricism of a Lynds. Penal reform in particular was experimental in the United States, because of the competition between the states engendered by the federal system, and because of the lively interest taken in it by public opinion (Penitentiary 47-48, 63-64, 126).

Neither Livingstonian utopianism nor Lyndsian empiricism by itself would have been as successful as the compound of them both. ${ }^{13}$ In France,

found innumerable institutions," including "the Pennsylvania public school system." Livingston was Andrew Jackson's Secretary of "State, who had earlier been "a lawyer, Congressman, District Attorney, and finally mayor of New York City."

${ }^{12}$ See also Pierson's characterization of Vaux (1938: 460n) as "näve, literary, and philosophic."

${ }^{13}$ Although I have been emphasizing Tocqueville's belief in the shortcomings of the theoretical idealism of democratic reformers, he undoubtedly thought that this theoretical idealism, when restrained by practical considerations and popular participa- 
as opposed to America, utopianism existed without an empirical corrective. "In most cases, philanthropy is with us but an affair of the imagination" (Penitentiary 123). In France, as opposed to America, utopian theorists did not allow themselves to be checked by the prudence and caution of the popular majority (Old Regime 281; cf. Penitentiary 51-52).

Theoretical excesses existed in the American penal reform movement; these excesses, however, did not discredit the movement as a whole. Beaumont and Tocqueville deny that one "must . . condemn this system on the exaggeration of writers who, preoccupied with philosophical doctrines, have not guarded themselves against the danger attending any new theory if carried to its full consequences" (Penitentiary 116). The American penitentiary system fails to attain the goal of radical religious reformation. Nevertheless, in spite of its failure to do so, it succeeds in bringing about a less elevated kind of reformation.

The zeal of religious instructors, which is often insufficient to effect a radical reform, has yet a great influence on that of the second grade... . Though the preacher does not often arrive at his proposed end, it is yet important that he should pursue it without interruption, and, perhaps, that point which we have indicated, is obtained only because the aim is taken much higher. (Penitentiary 90-91; see also the discussion of "Mr. Tukerman" on p. 207.)

\section{The Defense of Realistic Reformation}

In what does this "reform . . of the second grade" consist? Beaumont and Tocqueville contend that the penitentiary can lead the convict to approach what one might describe as the prudential morality of the ordinary American. Their hope is well expressed in the following passage:

Perhaps, leaving the prison he is not an honest man, but he has contracted honest habits. He was an idler, now he knows how to work.... Without loving virtue, he may detest the crime of which he has suffered the cruel consequences, and if he is not more virtuous he has become at best more judicious; his morality is not honor, but interest. His religious faith is perhaps neither lively nor deep; but even supposing that religion has not touched his heart, his mind has contracted habits of order, and he possesses rules for his conduct in life. (Penitentiary 90.)

Prisoners are unlikely to achieve the radical regeneration anticipated by the theorists of penitentiary reform; but the more modest improvement envisioned by the practitioners of penitentiary reform is attainable. Beaumont and Tocqueville's argument on behalf of the less elevated reformation again reflects Elam Lynds's influence upon them. For while

tion, had a vital role to play in improving democratic society. See Old Regime 156: belief in "the perfectibility of man" is "admirable": without it, "a nation can but relapse into a servile state"; with it, reformers can be "weaned . . . away from self-regarding emotions, stimulated to heroic deeds and altruistic sacrifices." This "idealistic" strain in Tocqueville's thought is also evident in his hope that greatness can continue to be possible in democratic times: see pp. 24-25 below. 
denying "that the counsels of the chaplain ... make a good Christian of [the convict]," Lynds also asserted "that a great number of old convicts do not commit new crimes, and that they even become useful citizens, having learned in prison a useful art, and contracted habits of constant labor. This is the only reform which I ever have expected to produce, and I believe it is the only one which society has a right to expect" (Penitentiary 164; see also the comment of Maxwell Willsee, "agent at Sing Sing," in Journey 208: reform is impossible "except in so far as the prisoners learn to earn their living").

In light of their preference for Lynds's views over Livingston's, it is hardly surprising that The Penitentiary System reflects an apparent preference for the "system of reformation" at "Auburn," which "does not rest upon so philosophical a theory"; the Philadelphia "system of reform," by contrast, "belongs to the highest philosophy" (Penitentiary 85). The Auburn system (Penitentiary 91) "is perhaps more conformable to the habits of men in society, and on this account effects a greater number of reformations." In addition (Penitentiary 104), "the prisons, constructed on the Auburn plan, are infinitely cheaper." Drescher (1968: 137n) notes that "the emphasis of Beaumont and Tocqueville's first work led later scholars ... to classify them as Auburnites."14

We have seen Beaumont and Tocqueville deny the likelihood of religious reformation. Nevertheless, the reformation which they propose in its stead could not be construed as a "secular" reformation. Although religion cannot produce the "radical reform" at which it aims, in its absence the reform "of the second grade" could not be achieved. In terms of both its achievements and its limits, this points to a partial analogy between the role religion plays in aiding the moral reformation of convicts

\footnotetext{
${ }^{14}$ For this reason, one notes with surprise that by 1837 , Beaumont and Tocqueville became advocates of the Philadelphia system. Three reasons may be suggested for this subsequent decision: (1) Beaumont and Tocqueville's personal dislike for Charles Lucas, a rival French prison reformer who supported the Auburn system (Pierson 1938: 712); (2) their growing conviction that in practice isolation could not be maintained in Auburn-style penitentiaries (Drescher 1968: 136-37); (3) their unwillingness to advocate a system dependent for its success upon the administration of corporal punishment ("Rapport" 313; Social Reform 75).

Even as an advocate of the Philadelphia system, however, Tocqueville was never to express much confidence in the possibility of radical reformation. See "Rapport" 321: "To suggest to a convicted adult ideas radically different from those that he had conceived until now, to inculcate in him wholly new sentiments, to change profoundly the nature of his habits, to destroy his instincts, to make in a word a virtuous man of a great criminal, that is assuredly such an arduous and a difficult enterprise, that one could succeed in it only rarely." We saw on p. 10 , above, that contemporary criminology lacks confidence in the practicability of the rehabilitative ideal; the evidence here and on pp. 14-15, above, suggests that there is less of a gap between Beaumont and Tocqueville's position and that of contemporary criminology than one might have supposed. For even when Tocqueville came to advocate the Philadelphia system espoused by the theoretical reformers, he maintained his realistic attitude toward the limits of reformation: "If it is not sure that the system of individual imprisonment, more than any other system, makes the convicts better than they were, at least it is sure that it prevents them from becoming worse; and that is an immense result, the sole result perhaps which it is prudent for a government to propose to itself" ("Rapport" 321; cf. Penilentiary 81).
} 
and the role that it plays in aiding the moral functioning of ordinary citizens in democracies. ${ }^{\text {is }}$

The convict's "religious faith" is "neither lively nor deep"; religion "has not touched his heart," but it has influenced his "mind," which "has contracted habits of order." It is clear from Democracy in America that this pragmatic, rationalistic acceptance of religion is characteristic of Americans generally: "it would seem that the head rather than the heart leads them to the foot of the altar." Americans "practice their religion out of self-interest," and "often ... place in this world the interest which they have in practicing it" (Democracy 530; see also 436, 448, 529). In America generally as in the American penitentiary specifically, religion fails on the whole to produce an other-worldly state of mind; it is nevertheless indispensable, because it produces habits of orderliness and reliability that are so conducive to success in this world. Tocqueville's description of "preachers in America" fits him as well as it does them: "it is often difficult to be sure when listening to them [as it is when reading him] whether the main object of religion is to procure eternal felicity in the next world or prosperity in this" (Democracy 530).

Religion can influence convicts as it does ordinary Americans: it can encourage them to be orderly, to restrain (although not to abolish) their acquisitiveness, to abandon the pursuit of instantaneous gratification, and to accept the lesser but legal pleasure of deferred gratification in its stead. In general, Beaumont and Tocqueville's realistic reform "of the second grade" was intended to produce nothing more (but also not much less) than the ordinary democratic human beings whose prosaic, unromantic qualities are so well described by Tocqueville in Democracy in America. The reformed convict is characterized by "honest habits," and a "morality ... of interest." He is "judicious," he "knows how to work," he "detest[s] crime." In all of these respects he is strongly reminiscent of democratic man, who is concerned "to produce well-being," who is characterized by "reason" (not "genius"), "tranquil habits" (not "heroic virtues"), and most significantly - by "vices" (not "crimes"), by "few transgressions" (if also by "few splendid deeds") (Democracy 245). ${ }^{16}$

${ }^{15}$ Because religion is prevalent in America but not in Francc, Beaumont and Tocqueville are skeptical as to the likelihood of the success of American-style penitentiary reform in France (Penitentiary 121-23); for the same reason, of course (among others), Tocqueville is skeptical as to the likelihood of the success of American-style political democracy in France (Democracy 290-301; Old Regime 148-57).

${ }^{16}$ The reformed convict and the ordinary American bear only a partial resemblance to one another, however. Perhaps they differ most strikingly from one another with respect to their positions on the continuum between isolation and association. As we have seen, Beaumont and Tocqueville contend that convicts must be isolated from one another if they are to be reformed (or at least not to be further corrupted); whereas Tocqueville calls upon free people to employ "the art of association" (Democracy 517) in order to maintain and expand their freedom. It is noteworthy that Beaumont and Tocqueville are both very well aware of and very much untroubled by the discrepancy between their prescriptions of isolation for prisoners and association for law-abiding citizens. See Penitentiary 76: "We understand perfectly well, that an assemblage of criminals, all of whom have infringed the laws of the land, and all of whose inclinations are corrupted, 
Nevertheless, the analogy between the convicts' religiosity and that of ordinary Americans is only partially valid. For Tocqueville at times expresses hope that religion can greatly influence the behavior of democratic man: Tocqueville is not wholly content with the view of religion as an agent that merely "restrain[s]" the democratic "taste for well-being" (Democracy 448); thus he also states that belief in the immortality of the soul is "indispensable to man's greatness" - and worries lest the "proper and legitimate quest for prosperity" lead democratic man to neglect his immortal soul, hence to "lose the use of his sublimest faculties" and "at length [to] degrade himself" (Democracy 544, 543). Significantly, in this respect one can discern a greater kinship between Tocqueville and the theoretical reformers than I have previously suggested; for Tocqueville's focus upon "man's greatness" points to a greater concern that man be perfected than I have previously imputed to him.

I will return to this point in my conclusion. For the moment, however, we should recall the limits to the kinship between Tocqueville and the theoretical reformers: to the extent that Tocqueville hopes that religion will greatly elevate men's conduct, he nevertheless tends to restrict his hope to ordinary citizens, and not to extend it to convicts. Although he occasionally expresses the hope that religion can elevate the ordinary citizen above the level of "decent materialism," he demonstrates the realistic character of his penitentiary reformism by hoping to elevate the convict only to that level - the level at which people "abstain strictly" from "physical delights that cannot be indulged without crime" (Democracy 534).

Understood in this modest sense of promoting "decent materialism," the reformation of prisoners is a realistic goal. ${ }^{17}$ To this extent Beaumont

and appetites vicious, cannot be governed in prison according to the same principles, and with the same means, as free persons, whose desires are correct, and whose actions are conformable to the laws." See also Drescher 1968: 139.

${ }^{17}$ Even this limited reformation, which I have been pleased to call "realistic," will, regrettably, seem laughably utopian in view of the rate of recidivism prevailing in the American penitentiary today. It is therefore important to remark that the intractability of the problem of crime in contemporary America might well come as no surprise to Beaumont and Tocqueville. Were they alive today, Beaumont and Tocqueville would conceivably not assert that "society in the United States is . . eminently religious"; furthermore, they would undoubtedly not assert that "the prisoner in the United States ... breathes in the penitentiary a religious atmosphere" (Penitentiary 122). Although one admittedly cannot prove that the decreasing influence of religion upon American life has contributed to the increasing intractability of the problem of American crime, speculation along such lines is suggestive and far from fruitless: see the discussion of the transition from nineteenth-century "impulse control" (fostered by religious belief) to twentieth-century "self-expression" (fostered by a decline in the power of religious belief) in Wilson 1983: 228-40.

In addition to emphasizing the impact of religion, Beaumont and Tocqueville also contend that American society's youth and economic growth went far toward explaining the solubility of the problem of American crime. "In America, where wages are extremely high, the convicts easily find labor when they leave the prison, and this circumstance favors their good conduct, when they have re-entered society." By contrast, ex-convicts "in France ... are not infrequently brought back to crime by a fatal necessity" (Penitentiary 131; see also 99). Arguably, twentieth-century America has come to resemble nineteenth-century France, in terms both of the decreasing influence of 
and Tocqueville vindicate the cause of penitentiary reform against the fatalistic attitude which would assert that human beings in democratic times can in no way control their institutions and their fates. Thus they do not believe "that nothing can be done towards the amelioration of our prisons" (Penitentiary 132); they deny that the "evil" of the prison (i.e., its tendency further to corrupt convicts, as opposed to reforming them) is "incurable," because they realize that "others have found means to eradicate [it]" (Penitentiary 135).

Nevertheless, Beaumont and Tocqueville's conception of reform differs greatly from that of the penitentiary theorists. The theorists commit the democratic error of stretching "the scope of human perfectibility . . beyond reason" (Democracy 454). The theorists exaggerate human perfectibility, in that their reformation attempts to convert the convict into a human type who is rarely to be seen, particularly among former criminals. In any case, the deeply religious true Christian whom they aspire to bring into being is more likely to be found in aristocratic societies than in democratic ones: "deep convictions" and "acts of profound devotion" are more likely to characterize aristocratic human beings than democratic ones (Democracy 245).

By contrast, Beaumont and Tocqueville limit the scope of penitentiary reform. One way in which they do so is by insisting that the reformation of convicts be classically liberal as well as democratic. ${ }^{18}$ Just as the rulers of the state should not attempt to restructure the souls of its subjects in the hope of inculcating moral purity, so should the administrators of a penitentiary not expect to succeed in such an undertaking with its inmates. ${ }^{19}$ Within the prison as well as outside it, reform instituted by government must be limited because classically liberal: it must aim to affect people's behavior, but can do little officially to promote altruistic religious motives as a basis for their behavior. ${ }^{20}$

religion upon society, and of the shortage of economic inducements that could motivate the released convict to obey the law; if this is so, Beaumont and Tocqueville's analysis can account for the ineffectiveness of twentieth-century American penitentiaries in reducing the rate of crime, in that it accounts for the ineffectiveness of nineteenth-century French penitentiaries in doing so.

${ }^{18}$ Beaumont and Tocqueville's reform is ultimately more democratic than is the theorists', although (and because) they do not commit the democratic error of the latter: for as we have seen, Beaumont and Tocqueville's reform is "founded on the interest of the mass."

1" Note the affinity between Beaumont and Tocqueville's position and that recommended by Wilson (1983: 49) to criminologists, who should, Wilson contends, learn to think like policy analysts: "[The policy analyst] would suspect . . . that changing the mental state of citizens is very difficult, quite costly, hard to manage organizationally, and liable to produce many unanticipated side effects." See also p. 50: "A serious policy-oriented analysis of crime ... would place heavy emphasis on manipulation of objective conditions, ... because behavior is easier to change than attitudes."

${ }^{20}$ Cf. Democracy $543,545-46$ : although "it is ever the duty of lawgivers" in democratic times to combat materialism, to further belief in the immortality of the soul, "to turn [men's] attention toward heaven," Tocqueville admits that "it is far from easy to say what those who govern democratic peoples should do to make [spiritual conceptions] prevail"; his sole suggestion is that governments "daily ... act as if they believed [in the immortality of the soul] themselves." 


\section{Convicts, Reformers, and Perfectibility}

To this point my analysis of The Penitentiary System has suggested that it was Beaumont and Tocqueville's concern to question the democratic belief in perfectibility, to cause it to be placed within narrower bounds. Thus I have repeatedly noted their skepticism regarding theoretical reformers, whose desire to do good too often and too readily exceeds their ability to do good. Beaumont and Tocqueville recognize the beneficence of the theoretical reformers' intentions and convictions, but insist that the reformers be judged by their impact and accomplishments instead of (or at least as well as) by their intentions and convictions.

Understood in this way, Beaumont and Tocqueville's position can be seen as a forerunner of the critique of idealistic reformers expounded by various hard-headed and unsentimental contemporary social scientists, such as Edward C. Banfield. Thus Banfield (1974: 273-74) claims that "the American political style was formed largely in the upper classes...., mainly by people of dissenting-Protestant ... traditions [such as the Quaker penitentiary reformers]"; he equates that style with "confiden[ce] that with a sufficient effort all difficulties can be overcome and all problems solved, and [with the perception of] a strong obligation to try to improve not only [one] self but everything else: [one's] community, [one's] society, the whole world"; he worries that because of this confidence and this perception, "we do not hesitate to attempt what we do not have the least idea of how to do," and that "we are not reconciled to - indeed, we do not even perceive - the necessity, so frequently arising, of choosing the least objectionable among courses of action that are all very unsatisfactory." 21

There is an undeniable similarity between Banfield's position and that of Beaumont and Tocqueville, but the two positions are not identical. I believe that it is fair to say that Banfield's position is that the idealistic reformers' conception of perfectibility is illusory, does more harm than good, and should be abandoned as an impossible dream. Beaumont and Tocqueville's position, by contrast, is somewhat more ambivalent, because their evaluation of the idealistic reformers is considerably more favorable.

It is true that Beaumont and Tocqueville also portray the theorists' conception of penitentiary reform as something of an impossible dream, and also criticize it for that reason; by referring to Democracy in America, however, we can see that in one respect Tocqueville praises it for the same reason as well. We can begin to understand this Tocquevillian ambivalence by recalling our earlier discussion of Tocqueville's two contrasting views of the role of religion in democratic society: in one view, religion is valued in that it serves to moralize the materialistic mediocrity of democratic society; whereas in the other view, it is valued in that it can serve to

${ }^{21}$ Cf. Tocqueville's formulation in his appendix on poor relief, in Du Système Pénitentiare 309 : legislation establishing poor relief gives birth to "extreme difficulties," which are "inherent." They are difficulties "whose number can be diminished by more or less perfect administrative procedures; but ... one must despair of seeing [them] completely disappear." 
some extent to elevate democratic society above materialistic mediocrity, by making "greatness" possible even in democratic society.

The ambivalence toward democracy that these views reflect is not restricted to Tocqueville's analysis of religion. A related ambivalence runs throughout much of Democracy, concerning the extent of and the reasons for the defensibility of democratic society: is democratic society defensible in spite of its mediocrity (Democracy 245) or because it is instead to some extent compatible with greatness? In discussing Beaumont and Tocqueville's analysis of the reformation of criminals, I have almost exclusively emphasized the first line of defense. Yet Tocqueville occasionally employs the second line of defense as well, which is evident in his suggestion that "distant goals" be set "for human endeavor" in "ages of equality," in his assertion that "the progress of the body social" depends upon "ambition['s]" having "force and ... greatness" (Democracy 547, 632).

Both lines of defense are already present, in embryo so to speak, in The Penitentiary System. We have seen the first in the impact that reform can make upon the prisoners: the second is evident in the impact that reform can make upon the reformers themselves. For evidence on behalf of human perfectibility is provided not only by the behavior of those who are supposed to be reformed: it is also provided by the behavior of those who do the reforming.

Tocqueville criticizes the materialistic mediocrity of democratic society: he views it as the forerunner to democratic despotism, in which the individual "withdraw[s] into himself," and "pursu[es] ... petty and banal pleasures" (Democracy 692). We have seen that this self-absorption and concern with production and consumption characterize the penitentiary, composed as it is of isolated and productive convicts. Tocqueville's prognosis of the possible evolution of democratic society clearly reflects his fear that democratic human beings may freely choose to isolate themselves from one another, or in effect freely impose upon themselves the isolation and exclusive focus upon economic production that is forcibly imposed upon convicts in the penitentiary. This is suggested by Tocqueville's occasional employment of the imagery of confinement and incarceration in Democracy - e.g., when he states that in democratic times "there is danger that [each individual] may be shut up in the solitude of his own heart" (Democracy 508; see also the allusions to being "shut up in himself," being "b[ou]nd ... in tight fetters," being "shut ... up more and more narrowly," on pp. 430, 436, 645). In part for this reason, "the most complete despotism" - i.e., the American penitentiary (Penitentiary 79) can justifiably be seen as the prototype of the new despotism into which, Tocqueville worries, democratic society may evolve (Boesche 1980: 550-52, 558-60).

Nevertheless, the new despotism of isolated individuals is just a worrisome possibility for the democratic societies of the future; Tocqueville does not regard it as an inevitability. For if a pessimistic outlook for democracy is prefigured in Penitentiary's analysis of the convicts, there is a sense in which a more optimistic outlook is prefigured in its analysis of the 
penitentiary reformers. The reformers were not "withdrawn into" themselves, and did not "pursu[e] . . petty and banal pleasures." Instead they united with one another in an attempt to benefit their society, and did not simply act to further their personal prosperity. Whatever the flaws in the reformers' proposals, the reformers were able to involve themselves and to involve others in an effort in which long-range goals and concern for others were able at least to supplement immediate goals and concern for self.

This praise for the reformers is apparent in Tocqueville's sole discussion of the penitentiary reform movement in Democracy in America. As in The Penitentiary System, his presentation of the reform movement is by no means uncritical: thus he points (p. 250) to its failure thoroughly to follow through on its reforms and to consider their consequences. Nevertheless, in Democracy as in Penitentiary, on the whole he depicts the zealous enthusiasm of the reformers favorably: the "exhortations" of "some pious people" brought about "the happy revolution" in which "the state of the prisons" was made "better." They did so by "rous[ing]" "the public," and causing it to "cooperate with . . eagerness" (Democracy 249-50).

Drawing on Tocqueville's analyses in Democracy, we can see that, in addition to benefiting society and the prisoners, the reformers' activity also helped to improve and perfect themselves: this is not the least laudable aspect of their activity in Tocqueville's view. For Tocqueville praises cooperative reformist activity not only (or perhaps even primarily) for its impact upon society; he also praises it for its impact upon the activists themselves. "It is incontestible that the people often manage public affairs very badly, but their concern therewith is bound to extend their mental horizon and shake them out of the rut of ordinary routine" (Democracy 243-44). Tocqueville defends cooperative activity because it reforms those who engage in it: it broadens their horizons by causing them to consider others as well as themselves. "Feelings and ideas are renewed, the heart enlarged, and the understanding developed only by the reciprocal action of men one upon another" (Democracy 515; see also 512-13). These discussions in Democracy of the benefits that accrue to cooperative activists as a result of their activity apply to the reformers described in Pexitentiary -in part because they presumably reflect Tocqueville's experiences with them and with similar reformers.

In short, The Penitentiary System presents us with two alternative images of democratic men: the convicts, the isolated materialists within the penitentiary, and the reformers, the cooperative idealists outside it. Beaumont and Tocqueville criticize the reformers for exaggerating the extent to which the convicts can be perfected; but they also praise the reformers for exemplifying the extent to which cooperative idealists can perfect themselves. Beaumont and Tocqueville are far from oblivious to the element of truth in the contention by Banfield (1974: 275), that "the reformer wants to improve the situation of the poor. .., not so much to make them better off materially as to make himself and the whole society better off morally"; but their work also suggests a sense in which Banfield's statement confers praise as well as blame upon reformers. 


\section{REFERENCES}

Banfield, Edward C. 1974. The Unheavenly City Revisited. Boston and Toronto: Little, Brown.

de Beaumont, Gustave, and Alexis de Tocqueville. 1833. Du Système Pénitentiare aux États-Unis, et de Son Application en France; Suivi d'Un Appendice sur les Colonies Pénales et de Notes Statistiques. Paris: H. Fournier Jeune.

1964. On the Penitentiary System of the United States and its Application in France. Translated by Francis Lieber. Carbondale and Edwardsville, Ill.: Southern Illinois University Press.

Boesche, Roger. 1980. "The Prison: Tocqueville's Model for Despotism." Western Political Quarterly 33: 550-63.

Drescher, Seymour. 1968. Dilemmas of Democracy: Tocqueville and Modernization. Pittsburgh: University of Pittsburgh Press.

Hobbes, Thomas. 1962. Leviathan or the Matter, Forme and Power of a Commonwealth Ecclesiasticall and Civil. Edited by Michael Oakeshott. London: Collier Books.

Lively, Jack. 1962. The Social and Political Thought of Alexis de Tocqueville. Oxford: Clarendon Press.

Locke, John. 1950. A Letter Concerning Toleration. Indianapolis and New York: Bobbs-Merrill.

Martinson, Robert. 1974. "What Works? - Questions and Answers About Prison Reform." The Public Interest (Spring 1974): 22-54.

Pierson, George Wilson. 1938. Tocqueville and Beaumont in America. New York: Oxford University Press.

Shils, Edward. 1972. "Intellectuals and the Center of Society in the United States." In The Intellectuals and the Powers and Other Essays, pp. 154-95. Chicago and London: The University of Chicago Press.

de Tocqueville, Alexis. 1968. Correspondence with Gobineau. Introduced, edited and translated by John Lukacs. In "The European Revolution" and Correspondence with Gobineau, pp. 177-340. Gloucester, Mass.: Peter Smith.

1969. Democracy in America. Translated by George Lawrence. Garden City, N.Y.: Anchor-Doubleday.

1960. Journey to America. Translated by George Lawrence. New Haven: Yale University Press.

1955. The Old Regime and the French Revolution. Translated by Stuart Gilbert. Garden City, N.Y.: Anchor-Doubleday.

. 1878. "Rapport à la Chambre des Députés sur la réforme des prisons." In Études Économiques Politiques et Littéraires, pp. 299-373. Paris: Calmann Lévy. and Gustave de Beaumont. 1968. Tocqueville and Beaumont on Social Reform. Edited and translated with an introduction by Seymour Drescher. New York, Evanston, and London: Harper Torchbooks.

Wilson, James Q. 1983. Thinking About Crime. Revised Edition. New York: Basic Books.

Zetterbaum, Marvin. 1967. Tocqueville and the Problem of Democracy. Stanford, Cal.: Stanford University Press. 